Chapter 6

\title{
D. Z. Phillips: Contemplation, Understanding, and the Particularity of Meaning
}

\author{
JOHN EDELMAN
}

In the last several years of his life, ${ }^{1}$ first in Philosophy's Cool Place ${ }^{2}$ and then in Religion and the Hermeneutics of Contemplation, ${ }^{3}$ D. Z. Phillips presented what he called a 'contemplative' conception of philosophy. Themes familiar to readers of his earlier work - e.g., his distinction between a philosophical understanding of the 'grammar' of a concept and the 'personal appropriation' of a religious or moral belief or principle; his criticism of what might be called 'classical' natural theology coupled with his rejection of the label 'Wittgensteinian fideist'; his insistence upon the 'neutrality' of philosophy in opposition to the 'advocacy' of particular moral or religious viewpoints - all of these still appear in these late writings. But the talk of philosophy as 'contemplative' seems to amount to more than a re-packaging of earlier ideas. Stephen Mulhall, in a review of Philosophy's Cool Place, ${ }^{4}$ speaks of a 'partial re-conceptualization' of Phillips's 'intellectual project' and identifies the impetus for it - surely rightly - in Phillips's editorial work on the papers of the late Rush Rhees. ${ }^{5}$ But perhaps this re-conceptualization is better described not as 'partial' but as 'incomplete' or 'unfinished'. Just several months before his death in July of 2006, Phillips was still unsettled in his thinking about this 'contemplative' conception. Toward the end of 2005, in the course of a discussion that had been going on between us for a couple of years, he wrote:

My question: If I want to say that Rhees's power as a philosopher comes from what he shows about [different religious and moral views] . . . and that he learns something AS A PERSON from all of this, how is this different from learning from one [of these views]? . . Rhees would never say that what he had learned was a kind of synthesis of all the possibilities. . . my main question is the kind of learning which comes through philosophical contemplation. 
One might expect that Phillips had already settled on an answer to his 'main question' in Philosophy's Cool Place. But even in the last chapter of Religion and the Hermeneutics of Contemplation - published two years after Philosophy's Cool Place - he wonders whether, in light of some of the arguments of his previous chapter, there is not good reason to question his 'contemplative' conception of philosophy. And the 'good reason' here is connected with the question he put to me about what is to be learned from philosophy so conceived: 'Does [this conception] not conjure up a picture of the philosopher hovering over the limitations and indeterminacy of our comprehension, or lack of comprehension [of different cultures and of one another in a single culture], understanding all he surveys? ${ }^{6}$ He continues: 'If our actual situation makes such transcendence impossible, why make it the aim of philosophy?' I do not believe he ever envisioned such absolute transcendence or the philosopher's consequent understanding 'of all he surveys' as the aim of philosophy. But he does seem to have thought that a philosopher could not carry out what he took to be 'the philosophical task of doing justice to different points of view, some of which react with radical incomprehension to each other" ${ }^{7}$ without attaining some measure, if not of transcendence, at least of disinterestedness regarding his or her own as well as others' moral or religious beliefs:

Philosophical contemplation, in trying to do justice to what it surveys, is not itself an attempt to arrive at a specific moral or religious viewpoint, but an effort to understand the kinds of phenomena we are confronted by in morality and religion. No doubt one's own moral and religious views will affect this endeavor but, nevertheless, they are different from it. ${ }^{8}$

His insistence on this difference, however, raised for him the question of what sort of personal significance there could be in philosophical contemplation. If the understanding that comes from such contemplation is so distinct from any moral or religious understanding, then what bearing can it have on the actual life I live? Thus, again, what is it that anyone might learn 'as a person' from the 'philosophical' consideration of different moral and religious points of view, that is, from 'philosophical contemplation'?

I do not think there is anything in the last chapter of Religion and the Hermeneutics of Contemplation that settles any of this, and evidently Phillips did not think so either. So I have taken up here the question he put to me in his letter. At the time, I did not think that I had any substantial answer to 
offer him, and I am not confident now that I have anything to suggest that he had not already considered. But I do find myself increasingly persuaded that there is in Rhees's own writings more of an answer to Phillips's question than Phillips appears to have seen there. In one respect, the thought is not very promising, for Phillips certainly knew Rhees's writings better than I could hope to know them. Nonetheless, there seem to me to be real difficulties in any attempt to reconcile Phillips's description of 'philosophy's hermeneutic, contemplative task' of doing justice to different points of view ${ }^{9}$ with a good deal of what Rhees does say about the understanding that can be found through philosophical contemplation. More precisely, it seems to me that Rhees's account of that understanding raises substantial questions about the talk of 'points of view', 'perspectives' and 'worldpictures' that is so much a part of Phillips's account of that contemplative task. Indeed, it appears to me that a growing awareness of these questions may be precisely what lay behind Phillips's question to me, and that that question reflects a movement toward a conception of philosophy's contemplative task rather different from the one he had so far articulated. My primary concern here, however, is not with biographical speculation but with the possibility of an answer to the question he put to me. Toward that end, I shall begin with some account of what Rhees and Phillips each means by 'contemplation' and of why each thinks it so important to philosophy, for even here, I think, significant contrasts quickly appear.

II

In the second volume of In Dialogue with the Greeks, Rhees writes:

Contemplation involves thinking of other possibilities. Socrates wants to find what is common - be it the form of beauty, of equality, or of a triangle. Being able to recognise the same thing - you do not know what it is until you know what form it can take. Recognising this possibility 'of the same sort of thing' may put the original matter in a new light. ${ }^{10}$

Rhees contrasts such contemplation in philosophy with 'practicality, the view that study is only important if it tells you what to do, how to get on', saying that, for Socrates, 'that is ignorance'. ${ }^{11}$ Phillips, too, talks of the contemplation of different 'possibilities' - different 'possibilities of sense ${ }^{12}$ or 'possibilities of moral sense'. ${ }^{13} \mathrm{He}$ also tells us that 'Rhees brings out how the philosophical concern with the possibility of sense is 
linked, in a contemplative conception of the subject, with wonder at the forms sense and saying something take for different people. ${ }^{14}$ He quotes Rhees at length from 'The Fundamental Problems of Philosophy':

Perhaps it is that thinking about the notions of reality and of understanding leads one to the threshold of questioning the possibility of understanding at all, and to wonder at the possibility of understanding. Wonder is characteristic of philosophy anyway, as it is of the thinking of less corrupted peoples. Wonder at death - not trying to escape from death; wonder at (almost: reverence towards) madness; wonder that there should be the problems that there are, and that they should have the solutions that they do. (Pythagoras treating the 'discovery' that any triangle inscribed in a semi-circle is right-angled, as divine revelation, as a word to be reverenced.) Wonder at any natural scene that is beautiful. Wonder at the beauty of human actions and characters when it appears in them. ${ }^{15}$

Phillips insists that Rhees is not saying that the wonder is the same in all of these cases; nor that those who wonder in these ways are engaged in 'philosophical wonderment at the different ways in which people think' ${ }^{16}$ But he does take Rhees to be suggesting that these other examples of wonder may throw light on the presence of wonder in philosophy, and that 'a failure to see any point in these examples is likely to be linked, in some ways, with a failure to see any point in a contemplative conception of philosophy. ${ }^{17}$ And yet, while Rhees does speak of 'other possibilities' as the object of philosophical contemplation, neither 'the forms sense and saying something take for different people' nor 'the different ways in which people think' are among the objects of wonder mentioned by Rhees in the remarks that Phillips quotes here. Nor, I believe, are these mentioned as objects of wonder in any of Rhees's other published remarks. What Rhees does identify as an object of wonder in the remarks quoted is simply 'the possibility of understanding', and this difference seems to me more than a matter of emphasis.

The remarks quoted by Phillips belong to a discussion of the sense we may have that there is an 'internal connection between what you are engaged on in philosophy, and the sort of life you lead'. ${ }^{18}$ Rhees notes how it might be suggested 'that we should be surprised to find anyone who was a serious philosopher and was at the same time a playboy or man about town'; and how we may feel 'that devotion to philosophy goes together with a certain asceticism in one's life, and a certain humility'. ${ }^{19}$ So he asks what there is 'about the questions of philosophy that should affect one's outlook on other things in this way'. ${ }^{20}$ The remarks about wonder belong to Rhees's 
answer to this question, and in them he seems to make two distinct points: first, that thinking about the notions of reality and of understanding may lead one constantly to the threshold of questioning the possibility of understanding at all; and, second, that it may lead one to wonder at the possibility of understanding. Unless I misunderstand him here, the wonder at the possibility of understanding is distinct from, though clearly related to, the questioning as to whether understanding is possible. It is wonder that understanding actually is possible, i.e., wonder that understanding is in fact attained by human beings. There is an obvious connection between such wonder and Rhees's evident preoccupation with problems of scepticism throughout many of his writings. ${ }^{21}$ But, of course, Rhees is not suggesting that if you just get thinking about the problem of scepticism or about the relation between thought and reality or about what is meant by 'It is' - the questions he identifies as the 'central' questions of philosophy ${ }^{22}-$ the result will be wonder and 'a certain humility'. In fact, quite to the contrary, he insists that to do philosophy one must be able 'not only to see questions where those not given to philosophy see none, but also to look on those questions in a particular way': 'Not wanting to dismiss the questions, nor "to get rid of them" through any sort of answer or to show that they are a sort of needless worry to be put out of mind. ${ }^{23}$ As he puts it in In Dialogue with the Greeks, the questions cannot be mere 'curiosities', nor can they be opportunities to test one's mettle or to 'meet the challenge', as though there were something here to master or to get the better of. ${ }^{24}$ In fact, Rhees comes back again and again to the idea that philosophy is not a skill or an accomplishment. ${ }^{25}$ To think it is and so to be caught up in any concern for recognition or for prestige or admiration ${ }^{26}$ can only get in the way of our attending to the questions or problems themselves, our trying 'to understand the questions - and from this angle or in this sense to understand human thinking and human investigation and human life; to understand how [these questions] arise in, and in one sense belong to, our thinking about other questions that we ask and answer. ${ }^{27}$

Part of what is to be emphasized here is that for Rhees it is not at all obvious what sort of questions the central questions of philosophy really are. ${ }^{28}$ If I understand him, the difficulty in seeing what the questions do amount to is at least part of the reason why 'Philosophers have almost always found that their discussions were in large part about what philosophy is. ${ }^{29}$ But it is precisely the desire to understand these 'central' questions and the consequent demand that we actually 'attend' to them that lead Rhees to 
speak here of 'contemplation of the ways in which people think and inquire - e.g., trying to solve problems in physics, or in connexion with moral problems'. ${ }^{30}$ Rhees thinks that such contemplation is especially difficult in a culture such as ours, preoccupied as it is with 'getting things done, with how to do things, with results' ${ }^{31}$ But the need for it goes with the contrast Socrates draws between the philosopher and the rhetorician who 'is always in a hurry'. ${ }^{32}$ The philosopher is not in a hurry because he is a 'philosopher', one caught up in the 'love of wisdom', or, as Plato presents it, the love of learning or of understanding (philomatheia). ${ }^{33}$ All of which is to say that Rhees's talk of contemplation is rooted in his conception of the character of any genuine interest in the questions of philosophy - that any such interest is an interest in understanding. ${ }^{34}$ But it should be added that for him that is also a very personal interest, if only because, as he sees it, a philosopher's interest in understanding is, largely at any rate, an interest in understanding how there can be understanding at all.

This is why it seems to me significant that while philosophical contemplation leads Rhees to wonder at the reality of understanding, it leads Phillips to wonder at 'the forms that sense and saying something take for different people' or at 'the different ways in which people think'. Indeed, on two occasions when, in Philosophy's Cool Place, ${ }^{35}$ Phillips quotes Rhees's remarks about 'contemplation of the ways in which people think and inquire', he does so in order to underscore the 'neutrality' of philosophy in opposition to the philosophical 'advocacy' of particular moral or religious views. I take the central point behind this talk of neutrality to be fairly straightforward, namely, that the notion that philosophy 'underwrites' any particular understanding of the moral life or any particular religious point of view - and so the notion of a 'philosophical perspective' from which to adjudicate between rival conceptions of the moral life or between different viewpoints on religious matters - is a fiction. ${ }^{36}$ In Phillips's view, the failure to see this is a failure to appreciate the nature of some of those conflicts or differences and so a failure to do justice to those different 'conceptions' or 'viewpoints' or, as he sometimes calls them, 'world-pictures'. ${ }^{37}$ I am not suggesting any necessary incompatibility between Phillips's concern to do justice to the different forms that understanding can take for human beings and the concern behind Rhees's own talk of philosophy as 'contemplative'. But, as I hinted above, I think there may well be an incompatibility between Phillips's description of 'philosophy's hermeneutical, contemplative task' in terms of 'perspectives' and 'world-views' and Rhees's account of 
the understanding that is, for him, an object of wonder. The very notion of such an incompatibility may seem suspect, given that Rhees himself, like Wittgenstein, often speaks of 'world-pictures'. ${ }^{38}$ But it is not the expression itself that is the issue. The question I mean to raise is whether Rhees's criticisms of Wittgenstein's talk of 'rules of language' and of 'languagegames' and especially the difficulties Rhees sees in Wittgenstein's use of the expression 'form of life' do not have an important bearing on what we are to make of Phillips's talk of 'perspectives', 'points of view' and 'world-pictures'. I shall argue that they do, and that they in fact suggest a sense in which one cannot do justice to the different understandings that human beings actually possess while retaining such talk. Indeed, to see this, I think, is to see how the use of those expressions can obscure the very personal significance that philosophical contemplation and the understanding that may come from it had for Rhees. No doubt, all of this will require a substantial account of Rhees's criticisms of Wittgenstein. But it may be best to begin with some account of how some of the difficulties that motivate those criticisms also appear in Phillips's talk of 'perspectives' and 'world-pictures'.

III

In the second volume of In Dialogue with the Greeks, Rhees writes:

Plato holds that where language and life are concerned, one has sense only if the other does - and only then. Only where it is possible for literature to say anything is it possible for science to say anything. You do not need philosophy to distinguish between true and false statements in these contexts, but it is concerned with the possibility of doing so - a possibility denied in philistinism and sophistic arguments. ${ }^{39}$

Rhees might have added, 'and denied by scepticism', for the sophistic arguments he has in mind here are expressions of the scepticism that is, I should argue, his chief concern both in Wittgenstein and the Possibility of Discourse and in the two volumes of In Dialogue with the Greeks. ${ }^{40}$ Indeed, at the conclusion of the second volume of In Dialogue with the Greeks he characterizes philosophy as 'the enemy of philistinism and scepticism'. ${ }^{41}$ When he says that you do not need philosophy to distinguish between true and false statements in literature or science but that the concern of philosophy is with the possibility of doing so, he is pointing to the sense 
in which philosophy's concern with scepticism is a concern with the possibility of 'saying something' at all. He takes this to have been a central concern through all of Wittgenstein's work, and it seems to me that much of his own criticism of particular aspects of that work turns on the question whether Wittgenstein provides us with an adequate response to scepticism, an 'adequate' response being one that shows clearly enough - or as clearly as one can - what Rhees might have called 'the reality of understanding'. In fact, the connections between the possibility of 'saying something' and the problem of scepticism, as well as the enduring place these held in Wittgenstein's thought, are brought out by Rhees in a passage often quoted or referred to by Phillips in connection with his own concern with the contemplation of 'possibilities of sense'. It will be helpful, I think, to give a very full version of the remarks to which Phillips frequently refers. ${ }^{42}$ They are to be found in Rhees's 'Some Developments in Wittgenstein's View of Ethics $^{43}$ :

In the period leading up to the Investigations, [Wittgenstein] would try to set down the way he had thought about logic in the Tractatus. For example: 'In logic we have a theory, and this must be simple and neat, for I want to know that whereby language is language. That all this which we call language has imperfections and slag on it, I agree, but I want to come to know that which has been adulterated. That whereby I am able to say something.' What the Tractatus says of 'the real sign' (das eigentliche Zeichen) or 'the real proposition' would illustrate this. And there is a similar tendency in what it says of ethics. 'The Ethical', which cannot be expressed, is that whereby I am able to think of good and evil at all, even in the impure and nonsensical expressions I have to use.

In the Tractatus he would consider different ways of saying something, in order to find what is essential to its expression. As we can see what the various ways of expressing it have in common, we can see what is arbitrary in each of them and distinguish it from what is necessary. Near the beginning of the Lecture on Ethics he says: 'if you look through the row of synonyms which I will put before you, you will, I hope, be able to see the characteristic features which they all have in common and these are the characteristic features of Ethics.'

When he wrote the Brown Book he would constantly describe 'different ways of doing it', but he did not call them different ways of saying the same thing. Nor did he think we could reach the heart of the matter by seeing what they all have in common. He did not see them as so many fumbling attempts to say what none of them ever does say perfectly. The variety is important - not in order to fix your gaze on the unadulterated form, but to keep you from looking for it. 
Rhees here describes a profound change in Wittgenstein's thinking about logic, language, and the possibility of 'saying something'. The change is a change in Wittgenstein's understanding of the differences in the ways people speak and so, we might say, in his understanding of the different forms that understanding can take in different people's lives. Wittgenstein gives up the search for 'the unadulterated form' behind such differences. But Rhees's description of this change does not, I think, make it immediately clear why that search ought to be abandoned. The description was not, I think, intended to make that clear. But the result is that it is not immediately evident how attention to 'differences' - attention to the 'variety' - is supposed to 'keep me' from looking for 'the unadulterated form', especially if it was those differences that led me to look for it in the first place. Just how those differences might in fact send one off on such a search is brought out by Rhees in this same essay when he reports Wittgenstein as saying:

'People have had the notion of an ethical theory - the idea of finding the true nature of goodness or of duty. Plato wanted to do this - to set ethical enquiry in the direction of finding the true nature of goodness - so as to achieve objectivity and avoid relativity. He thought relativity must be avoided at all costs, since it would destroy the imperative in morality. ${ }^{44}$

But, again, if a concern over an apparent relativity in ethical judgements arises - as it commonly seems to do - in face of the variety of conceptions of 'the moral' found among human beings, how is contemplation of that variety itself to keep me from looking for 'the unadulterated form' unless, perhaps, I have already come to look upon that variety differently. Apparently, what I need to do is to recognize that talk of an 'unadulterated' form or essence is an expression of some misunderstanding. The difficult thing is to see how the evident variety in ways of speaking about the 'moral' or the 'ethical' can be understood neither as obscuring an 'unadulterated' form nor as leading us into 'relativism'.

I have given so lengthy a quotation from Rhees in order to set the developments in Wittgenstein's view of ethics that are the subject of Rhees's essay in the context of Wittgenstein's more general concerns in philosophical logic, which appears to have been Rhees's own point in the quoted passage. He is bringing out the sense in which the problem of 'relativity' in moral judgements is in many respects only a special case of a more general scepticism that can leave me wondering whether it is possible to 'say 
something' at all. Wittgenstein's concern to find 'that whereby I am able to say something' arises, I take it, from the apparent possibility that despite the words or sentences that I appear to use well enough, the language I speak might somehow fail to get at the reality of things. ${ }^{45}$ But a search for the 'form' or 'essence' of 'the moral' or of 'the good', like any search for the form or essence by which I am able to say anything at all, cannot be what we would normally call an 'empirical' search, meaning by that the sort of search involved in determining whether there are any shoes in my closet or any signs of life on Mars. The problem of correct identification here belongs to 'logic', at least in the sense in which Wittgenstein remarks that 'essence is expressed by grammar. ${ }^{46}$ If the 'unadulterated form' is somehow behind or beneath the 'imperfections' and 'slag' that belong to the grammars of the languages people actually speak, I may well wonder how any 'unadulterated' form or essence is to be identified at all. To say that 'essence' is expressed by 'grammar' is to acknowledge that I cannot identify any such essence apart from the grammar of a language that people actually speak. I take this to be Rhees's point in Wittgenstein and the Possibility of Discourse when he remarks that Protagoras would have been right to reject 'the idea of some criterion for intelligibility' or some 'definition of a language' which is 'behind or beyond what people actually practice'. ${ }^{47}$ And there is no reason to think he would say anything different about a search for a definition of the 'ethical' or the 'moral'. Yet when Phillips has himself rejected such a criterion, this seems to have led others to criticize him for 'conceptual relativism', the view that 'there is no way things are except relative to some conceptual scheme'. ${ }^{48}$

Sometimes, I think, Phillips does speak in ways that suggest some kind of relativism. For example, in his 'Postscript' to Rhees's Wittgenstein's 'On Certainty': There, Like Our Life, he speaks of the possibility of a 'fundamental disparity' in 'the way things are taken' (my italics). ${ }^{49}$ But it seems clear enough in The Hermeneutics of Contemplation that he thinks it confused to say 'there is no way things are except in relation to some conceptual scheme'. The confusion is in the idea that 'the language in which we express our beliefs, true or false, is itself a set of beliefs about reality' ${ }^{50} \mathrm{In}$ rejecting such a notion as confused, he is not only rejecting the notion that there is some same 'reality' that different languages attempt to describe in different ways, but also the notion that they attempt to describe different realities. He follows Peter Winch in insisting that different languages 'do not describe anything at all'. 51 This does seem a clear enough rebuttal of 
'conceptual relativism'. If the language I speak is not itself a description of anything, then clearly it will be confused to speak of 'things' standing 'in relation to' conceptual schemes. What is not clear, I think, is that this will serve as much of a response to the scepticism of which Rhees takes philosophy to be 'the enemy'.

There is surely something right in the idea that the language I speak is not itself a description of anything - at least not in the way that a map can be said to describe a terrain, an analogy that Rhees explicitly rejects:

You can check a map to see whether it is accurate by looking outside it. But you cannot check language to see whether it is accurate by looking outside it. ${ }^{52}$

And, again, it may seem fair enough to suggest that a failure to see what is wrong with such talk is often behind the failures of philosophers ${ }^{53}$ and social scientists ${ }^{54}$ to do justice to the variety of forms that understanding can take in the lives of human beings. And that is itself to say that those failures are often rooted in confusions about the nature of language and, in particular, about what is often spoken of as the 'relation' between language and reality - precisely the sort of issues that Rhees identifies among the central problems of philosophy. ${ }^{55}$ But just as there are differences in what Rhees and Phillips identify as the object of philosophical wonder, so here there are differences in the concerns that commonly show when each talks of these central problems. Rhees's concerns center not so much on the bearing of these problems upon our understanding of one another or upon our understanding of the differences or distances that can separate us but on the bearing of these same problems upon our sense for the reality of our own individual lives. What is more, it is just here that his concern with these issues shows itself to be so very 'personal', as, for example, in the thoughts he imagines himself expressing thus:

'The importance of laws of reason or of thought is not simply that you could not make yourself understood to other people except you follow them; it is rather that you could not have any understanding yourself. The possibility of understanding is not simply the possibility of communicating. It is the possibility of distinguishing waking from nightmare. ${ }^{56}$

He comments: 
That is why philosophy has been in a way a matter of much more personal concern than science has. A matter of settling one's own difficulties; of coming from darkness into light - where this is a personal darkness and a personal light.

Philosophy is a matter of more personal concern because philosophical problems, unlike problems in the sciences, are 'problems which leave you wondering where you are ... taking all the reality out of things ...57:

Suppose we said that the 'point' of language or of speaking was intelligibility, or understanding. That that is what you learn when you learn to speak. The philosophical difficulties expressed in scepticism seem to call all that in question; call in question the possibility of learning anything in that sense - the possibility of understanding people. The possibility of saying anything. The possibility of learning or of growing wiser. The possibility of the growth of understanding. It is in this sense of doubting whether it makes any difference what you say not doubting whether there is any difference in meaning between one statement and another. That is rather important. Whether it makes any difference what you say - whether there is any point in it anyway; whether there is any point in saying anything anyway. ${ }^{58}$

Rhees here identifies a scepticism that is not, I think, to be answered by any insistence that the language I speak is not a description of anything. To the contrary, it may seem only to be bolstered by talk of 'different languages' or of 'world-pictures' and 'perspectives' - despite any denials that these are themselves descriptions of anything. No doubt there is an important sense in which the language I speak is not a description or map of anything. And this may be sufficient reason to say, as Rhees does, that the language I speak is not 'responsible to anything', at least not to anything to which it might be judged 'adequate' or 'inadequate'. ${ }^{59}$ So one may agree as well that it is confused to ask whether my own or anyone else's 'worldpicture' is either 'adequate' or 'inadequate'. ${ }^{60}$ But, again, this may seem only to make all the more doubtful what Rhees calls 'growth of understanding', the kind of growth that scepticism, as he sees it, calls into question. For surely none of this talk of different 'languages' or 'worldpictures' or 'perspectives' rules out the possibility of 'movement' from one to another 'language' or 'world-picture' or 'perspective'. To the contrary, such movement seems to be just the sort of change that over many years preoccupied Phillips in his own writings. ${ }^{61}$ Thus, in The Hermeneutics of Contemplation he remarks that we "need to see the importance of the distinction between making a mistake within a moral or religious viewpoint, and coming to regard one's viewpoint as mistaken. ${ }^{62}$ No doubt, any ac- 
count of these two possibilities will require two very different conceptions of 'mistaken', and in of his 'Afterward' to Rhees's Wittgenstein's 'On Certainty': There Like Our Life, ${ }^{63}$ he suggests that a change from one 'worldview' to another 'would be more like an initiation than the correction of a mistake.' But while a good deal might be said to fill out the notion of 'initiation' here, what I am in the course of arguing is that, in relation to the scepticism that is Rhees's concern, nothing will quite be enough as long as we do talk of change or movement from or into a 'world-view' or a 'worldpicture'. The mere possibility of movement from one 'world-view' or 'world-picture' to another may leave me wondering in what sense it matters what I do say or what 'language' I do speak. For insofar as there is no sense to the judgement that any given world-view or world-picture is the right one, there does not seem to be any sense to the judgement that this or that world-view or world-picture is better than another. Harking back to Rhees's talk of 'growth of understanding' in the last passage I quoted from Wittgenstein and the Possibility of Discourse, the point might be put by asking whether growth of understanding must be growth within a 'language' or 'world-view'. It may be that a person who comes to have a different world-picture or comes to speak a different 'language' will want to say that he or she has grown in understanding and so has come to a better 'perspective'. But it is hard to see how this could be anything but a confused expression of the fact that he or she has come to that new perspective. Whatever such a person might want to say, what philosophy seems to say again and again is that there is no sense to talk of better or worse here, given that there is no sense to talk of a 'more correct' or 'more mistaken' 'language' or 'perspective'. Which, again, is precisely what may lead one to wonder what difference it really makes that I have the perspective or world-view that I do have. I am suggesting that it should instead lead us to question in what sense, if any, actual individuals have 'perspectives' or 'world-views' at all. ${ }^{64}$

\section{IV}

I have tried to indicate how some of the difficulties that motivate Rhees's criticisms of Wittgenstein - difficulties connected with the problem of skepticism - also arise in connection with Phillips's talk of 'world-views' and 'perspectives'. Those criticism themselves, I believe, turn on what Rhees calls 'the problem of the particular and the general in language', as I shall now try to make clear. Rhees thinks, as Phillips himself brings out 
well, ${ }^{65}$ that much of Wittgenstein's talk of rules of language and of language-games may leave us with 'too external' an account of language, and so with an account of understanding that is inadequate to the challenge of the scepticism of which Rhees says that philosophy is 'the enemy'. But the point is not at all that Rhees sees no merit in Wittgenstein's talk of rules of language and of language-games and forms of life. As he observes in 'Some Developments in Wittgenstein's View of Ethics', if I am to say of a judgement that it is a 'moral' or an 'ethical' judgement, there must be some 'grounds' for my doing so: 'There must be grounds for saying that people who follow a particular system are making ethical judgements: that they regard this or that as good, and so forth', though, as he insists, it does not follow that what those people say must be an expression of something more ultimate. ${ }^{66}$ The point is that without such 'grounds' there would be no distinction between using the words 'moral' or 'ethical' rightly and using them wrongly. In this sense, then, there must be rules for the use of these terms. And yet no statement of such a rule can tell me its own application. Thus Wittgenstein at Philosophical Investigations \#201:

This was our paradox: no course of action could be determined by a rule, because every course of action can be made out to accord with the rule. The answer was: if everything can be made out to accord with the rule, then it can also be made out to conflict with it. And so there would be neither accord nor conflict here.

When Wittgenstein goes on to say that our troubles here show 'that there is a way of grasping a rule which is not an interpretation, but which is exhibited in what we call "obeying the rule" and "going against it" in actual cases', he is drawing us back to the sense in which obeying a rule is a 'custom' ${ }^{67}$ or, as he had put it in Philosophical Investigations, \#202, a 'practice'. But not, he wants to say, a practice I could engage in in 'logical privacy', for that would do away with any distinction between my thinking I was obeying a rule and my actually obeying it. ${ }^{68}$ Hence, to act in accord with a rule - to use a word in its meaning and so to say something - is to participate in an activity involving us - some 'us' - in common 'judgements':

If language is to be a means of communication there must be agreement not only in definitions but also (queer as this may sound) in judgements. This seems to abolish logic, but does not do so. ${ }^{69}$

I take it that this seems to abolish logic because logic was supposed to guide me in my judgements. ${ }^{70}$ Logic was to tell me what can be said or 
thought, what follows and does not follow from anything I do say. But if a rule cannot tell me its own application, and so I must fall back to some 'agreement in judgements', it may seem that I will be falling back to an agreement in 'opinions', an agreement in opinions as to what is 'in accord with the rule'. And while Wittgenstein famously remarks that agreement in the language people use 'is not agreement in opinions but in form of life', 71 it is also true, as Rhees remarks, that Wittgenstein did not make very explicit or very detailed what might be included in this idea. ${ }^{72}$ Rhees himself thinks that it will be very easy to go wrong here if we think that to imagine a language is to imagine what we might call a 'way of life'. ${ }^{73}$ But he also rejects talk of language as an 'institution" ${ }^{, 74}$ or as an 'instrument ${ }^{, 75}$ or even as an 'activity' - at least if you take building or marketing as examples of activities. ${ }^{76}$ So, too, he objects to the idea that the ability to speak is 'a matter of being able to follow a rule' ${ }^{77}$ If the problem, then, is that all of these ways of speaking may leave us with what Rhees calls 'too external' an account of language, ${ }^{78}$ we need to understand what 'too external' means here; and that, I take it, turns in large part on Rhees's distinction between 'understanding what is said' and 'knowing the rule for the use of the expression':

Understanding what is said, does not simply mean knowing the rule for the use of the expression. If you thought it did, you would not have understood what was meant by speaking of a rule for the use of an expression at all, or by a rule of language. ${ }^{79}$

You might, for example, be confusing a rule of language with a rule in a calculus:

In a calculus, I suppose you might say that if he knows how to use all the expressions involved, and that if he is familiar with all the procedures, then he ought to be able to follow the calculation. He ought to be able to follow a mathematical argument. But in connexion with ordinary discourse or discussion it is not just like that. ${ }^{80}$

It is not just like that in 'ordinary discourse' because in ordinary discourse you say something, whereas 'in mathematics you do not say anything. ${ }^{81}$ The difference 'has to do with the fact that in mathematics you can calculate what can be said'. ${ }^{82}$ You do not say anything because what 'makes sense' in a calculation is entirely determined by the calculus - and not by the context, let alone the particular speaker. ${ }^{83}$ That is part of the sense of saying that you can 'apply' a calculus: what is applied in this or that con- 
text is not itself affected by the context. Adding up oranges is no different from adding up fatalities in a train wreck - as 'adding'. But Rhees wants to say that what a person says in a conversation does get its sense from the context. If we are discussing the fatalities in a train wreck, I will be completely baffled if you suddenly tell me that you ate oranges at breakfast this morning. 'What is the point of saying that?' In fact, it is just this connection between the sense of what you say and the context in which you say it that suggests that saying something is more like making a move in a game than it is like calculating.

It makes sense for a batter to bunt with a runner on first and nobody out but with a runner on first and two men out we should perhaps say, 'It depends'. What kind of bunter is this batter? How deep is the infield playing? But even if saying something is more like making a move in a game than it is like doing sums, still, a game is something 'apart' from people's lives, as a conversation is not. ${ }^{84} \mathrm{~A}$ conversation, as Rhees would say, is about something and so is connected with and makes a difference to the conversants' lives outside the conversation. The playing of a game is not in this way connected with and does not in this way make a difference to the lives of the players outside the game. As Rhees observes, even in the case of a professional player, for whom the game is not a mere diversion, 'what happens in the game is not about - it does not have to do with, it does not get its sense from - what happens in the rest of his life'. ${ }^{85}$ His point, I take it, is that a conversation about painting a house or about performing surgery 'Don't you really need to use oil-based paint for this surface?'; 'Should we put the surgery off for another week?' - is not a game precisely because of the connections of meaning between the things said in these conversations and the rest of life. ${ }^{86}$ What it means to say that oil-based paint is 'the only real choice here' is essentially connected to the point we see in painting houses at all. And this fact points to a difference between learning to play a game and learning to speak a language. If what is said in a conversation or discussion gets its sense from the context - i.e., from something outside the conversation itself - then I cannot learn to converse or to discuss without some understanding of things outside the conversation. When Rhees speaks of an account of language as too 'external' he means that it is an account according to which one might engage in conversation without that understanding of the connections between what is said and the rest of life as that is lived by those engaged in the conversation. ${ }^{87}$ But in that respect, it will not be an account of language or of taking part in a conversation at 
all. Perhaps it will be closer to an account of what it is to take part in the sort of 'pretend conversation' one might have in learning a foreign language. But Rhees's point is that in such a 'pretend conversation' no one really says anything at all:

If you are giving me a lesson in a foreign language, we may carry on a sham conversation to give me the opportunity of constructing appropriate sentences and giving appropriate replies. Neither of us learns anything from what is said in a sham conversation of this kind, because neither of us really tells the other anything. And unless there were the distinction between genuine speaking and sham or pretence, then speaking would be nearly like playing the game correctly. You could say what you have been trained to say without telling anyone anything. ${ }^{88}$

Or, as he remarks somewhat later:

If you just learned the rules and learned how to construe odd remarks, or if it were really something like learning a game, and your teacher said, 'Now let's play. I'll move here ...' etc., or: 'Now let's play. I'll say this. Now what are you going to say?' this would be a game, all right, and what you say would be determined by what is possible according to the rules, and by what you could think of. But there would be no reality in it, and neither of us would be telling one another anything. ${ }^{89}$

The 'reality' of an actual conversation comes with the fact that you are talking about something, so that what you say is determined by something outside the 'rules for the use of expressions' and whatever you happen to think of. But that means that there comes into play a person's understanding of whatever it is that the conversation is actually about, which is why, having recognized a distinction between 'understanding what is said' and 'knowing the rule for the use of the expression', we have to notice a further ambiguity in 'understanding what is said':

'I understand what he said, but I could not see the point of saying that. Why didn't he tell us that Napolean lost the battle of Waterloo, or something?' So in one sense of 'understanding what he said', you did not understand it; or as we say, you did not understand him. It just meant nothing to you. ${ }^{90}$

Where I cannot see 'the point of saying that' I cannot see how what he said belonged to the conversation. It seems he might just as well have told us that Napolean lost at Waterloo. On the other hand, I may also be baffled by what a person says because what he says seems so obvious that it could not have been worth saying - unless, perhaps, we are not really talking about 
the same thing. But that in fact is what is important about each of these possibilities, namely, that each points up not only the way in which a real conversation involves a common understanding of something outside the conversation - and so of something more than might be captured by any account of the rules for the use of the expressions that are found in the conversation - but also what sort of limits there may be to that common understanding. That is, each of these cases brings out the way in which a real conversation involves the speakers' particular understandings of what the conversation is about. In a real conversation, a conversation in which there is no question about a person's mastery of 'the rules for the use of expressions', if I am puzzled by something another person says, this will not normally be because I need an explanation of what her words mean or how those words are commonly used, as may well be the case in the sort of practice conversation that goes with learning a foreign language. In a real conversation I will ordinarily want to ask what she meant by those words or why she said that. The point will be to understand what she is saying, to understand her, where 'understanding her' is not a matter of understanding 'people in general'. So while we do speak of understanding 'what the words mean' and 'what people usually mean when they say that', there is also a question that may be asked about what she meant when she said it. In understanding her I have not understood everyone or anyone else who might 'say such a thing'. In fact, to understand her is to see her as someone who can bring something to a conversation, ${ }^{91}$ and not merely as a representative of a 'perspective' or 'world-view'. It is to recognize what I want to call 'the particularity of meaning'. Thus Rhees remarks:

Other people may repeat what Leonidas or Caesar or Napolean or Bismarck said on a particular occasion. But they are not making the remark themselves. Even where similar situations recur and people say the same thing ('Will you marry me?'), then in one sense it is not the same remark. ${ }^{92}$

Even where people say the same thing, they do not say the same thing and not merely because 'you' and 'me' signify different individuals. Six months or three years later it may well be a genuine question what he was saying when he said 'marry'. But while a person may say something in a conversation that makes me wonder what he could mean by it and so makes me wonder whether we are really talking about the same thing, I may wonder in a very different way in yet a different sort of case. This is the sort of case in which I am quite sure that you did not mean what I took your words to mean, precisely because in that case what you said would 
have been just foolish: 'He can't have meant that; that would have been just silly. ${ }^{93}$ Rhees comments about the puzzlement that may occur in trying to understand what is said in the Bible:

And if I raise objections and criticisms, it is not because I think that what I read there is stupid; although it may be because I cannot see clearly what the difference is between what is said there and something that would be stupid, or at least open to obvious objections. ${ }^{94}$

I have said that to understand a person is to see that person as someone who can 'bring something' to the conversation. In some cases it may just be information that a person brings, but even then the person will have to understand the relevance of that information to the conversation. Still, it is a different sort of case that Rhees describes when he speaks of reading the Bible. The case of the Bible brings out the connection between the particularity of meaning and the possibility of a kind of learning distinct from the gathering of information, a learning in which I come to see sense where previously I did not. No doubt, this sort of learning would not be possible if there were no 'rules of language'. But it seems to depend as much on, again, what I am calling 'the particularity of meaning'. In this way it brings into view the problem of 'the particular and the general' in language:

You can understand what is said even though it is not said to you; you can understand what is written here although it was not written for you (and has nothing to do with the situation in which you are); you can understand what is told in a story or what is recited in a play, even though it is not written or uttered for anyone in that sense at all.

And I say this creates a difficulty, because it makes it seem as though learning to understand - or learning to understand what is said - is not like, or need not be like, learning to understand people. ${ }^{95}$

And shortly thereafter:

Part of the difficulty about the particular and the general, or the particular and generality in language has to do with grammar and vocabulary of course. When people are speaking, they are always saying something which, so far, seems to be as particular as the particular steps they take or strokes they strike. And on the other hand, they say it in this vocabulary and grammar. ${ }^{96}$

If there were no generality in language nothing could be said. But too great an emphasis on the general gives us what Rhees objects to as 'too external' 
an account of saying something - and that means 'too external' an account of understanding what is said. We get an account that makes speaking seem like the application of a technique, ${ }^{97}$ with the result that we take the 'reality' out of a discussion or conversation. ${ }^{98}$ The reality in a discussion is connected with the fact that the conversation is about something and so depends on our having some common understanding of something outside the conversation. On the other hand, if we had nothing but a common understanding, then, I think, there would be no discussion in that case either, for there would be nothing to learn. The point seems to me particularly important if we go on to ask what it is that we need a common understanding of in order to have a discussion or conversation. So, for example, you might be able to distinguish between oil-based paint and latex paint without seeing the point of using one rather than the other. For that, you would need to see the connection between the results of using one or the other and the point - or various points - behind our painting houses at all. And yet that is itself connected with the point of our living in houses and so with the various considerations that go into living in the sorts of houses we do live in - all of which considerations open up possibilities of disagreement and perhaps of incomprehension. I take it that this is, roughly, the line of thinking that leads Rhees to say that a dialogue 'makes sense - or anything that is said has sense - only if living has sense; not otherwise'. ${ }^{99}$ He recognizes plenty of difficulties that come with saying this. But if I can bring out the sense in which whatever 'sense' living has cannot be identified with any 'perspective' or 'world-picture' but is instead more particular and so more personal than such expressions are likely to suggest, I can perhaps being out something of what Rhees may have learned as a person from philosophical contemplation.

V

Whether living has sense - this is rather like asking whether understanding is possible. Not only 'rather like'; it is the same question. To see this is the same as seeing how discourse is possible. ${ }^{100}$

So to say that discourse is possible is to say that understanding is possible, and to say that understanding is possible is to say that 'living has sense'. But this suggests that 'Living has sense' takes us no further than 'Understanding is possible'. Indeed, Rhees himself remarks parenthetically, 'If we said, "Understanding is possible if living has sense", that would amount to: 
"Understanding is possible if understanding is possible.",101 On the other hand, by speaking of 'whether living has sense', Rhees emphasizes that there is nothing of what he means by 'understanding' here without what he calls 'understanding life'. ${ }^{102}$ As he puts it:

[Y]ou can understand what is said only if you can understand the discourse in which it enters. In other words, if you can talk of the meaning of things, or the sense of things, or the reality (point) of things. ${ }^{103}$

No doubt children say things and understand things said to them while having little or nothing of what we might call 'an understanding of life'. Nor is speaking always 'discourse' or discussion and, in fact, generally, it is not. ${ }^{104}$ Moreover, we do speak of 'communication' between even machines ${ }^{105}$ and between animals. ${ }^{106}$ But machines do not in the relevant sense 'speak to one another' or 'say anything', if only because they do not understand anything they 'say'; and they do not understand anything they 'say' because they have no lives in which it matters to do or say one thing or another, so that 'for them' there is nothing that their 'talk' is about. So, too, while we do speak of animals living together, this has not the sense it has when we speak of human beings living together:

When we speak of human beings as living together, we think of them as understanding or trying to understand, and misunderstanding one another. We think of the tasks and difficulties and satisfactions of living together. And whether they can make a go of it depends on whether they can keep some sort of understanding. But for animals there is nothing to understand, in this way. Animals may have regular companionship, as they may also have mates, and they may keep together or they may fall out. But there is no question of understanding here, any more than there is any question of discussion. ${ }^{107}$

In many respects, there is often little question of discussion with children either. But in learning to speak, they are learning to discuss - or they are not. But if it is the latter, then to that extent they will not know what they are saying, nor, often enough, will they understand what is being said to them:

If someone learns to speak, he does not just learn to make sentences and utter them, nor to react to orders either. He learns to say something. He learns what can be said; he learns - however fumblingly - what it makes sense to say. . . . And to do this he must learn how remarks hang together, how they may bear on one another. ${ }^{108}$ 
Part of what this means is that in learning to speak one becomes involved with the questions, criticisms and objections that belong to trying to understand a given remark. For trying to understand a given remark is trying to see how it belongs to the conversation or discussion, and that means trying to see how it is connected with what we are talking about. But the notion of 'what we are talking about' takes us to Rhees's talk of seeing the 'sense' of things or the 'point' of things. Or, perhaps, not doing so, in which case the discussion itself will seem pointless and I will not understand what is being said, even if I understand 'what the words mean'.

Rhees's point, then, is not that I cannot say anything or discuss anything unless I see the sense or point of 'life'. Rather, his point seems to be very much Plato's point that the sophists were 'in darkness about what speaking is' - even while they could speak:

They were 'estranged from that with which they have most constant intercourse' - without understanding of their own speech or thinking. And yet of course they did understand what is said to them, in ordinary matters anyway, as well as Plato did, and they could answer as clearly. ${ }^{109}$

Rhees thinks that on Socrates's view I would reveal this sort of 'estrangement' when I found myself unable to answer questions or meet objections to or criticisms of what I did say. ${ }^{110}$ Part of the trouble with all of this, however, is precisely that in ordinary matters or perhaps in various skills and techniques, or even in what some people understand by 'science', we do seem to have cases that are so much more obviously cases of understanding than anything that Rhees seems to mean by 'understanding life'. One big reason why they are more obviously cases of understanding is that the measure of anyone's possession of such 'understanding' is itself so much more obvious:

There are certainly difficulties in connexion with the notion of the measure of this understanding. In other circumstances we can ask how one would find out whether he had understood or not; we can give a pretty straightforward account of what it would mean to say that he had misunderstood; we can speak of criteria and so on. But in the present case it is by no means so clear what it would mean to say that someone had misunderstood. ${ }^{111}$

But he also sees a problem in the notion that the sorts of understanding for which we have a measure can stand as 'understanding' without the sort for which the measure is not nearly so obvious. For without the latter understanding, the former seem to break down as cases of understanding. So, for 
example, if the skills and arts acknowledged by the sophists are to be skills and arts, they must belong to a life - where 'belong to' signifies the having of some intelligible relation to what else belongs to that life, i.e., what else has an intelligible relation to that life. That is part of what it means to say that they are skills and arts. But the relation they do have to that life must also be distinct from the relation between, say, mere diversions or forms of entertainment and the rest of that life. But even to see such a distinction requires some conception of the sense of things or the point of things. In particular, it requires some conception of 'better' and 'worse' in the practice of those skills or arts that is different from any 'better' or 'worse' that belongs to the playing of a game. That means seeing their 'point' as somehow distinct from the point of any game. And part of what is important here is that if I could give an account of 'better' and 'worse' in the practice of a particular skill or technique it could not itself be given solely in terms of another and perhaps more 'comprehensive' skill or technique. For that would in turn call for a similar account, and one that could not itself, then, be given solely in terms of 'competence' or 'proficiency'. This is at least part of what leads Rhees, as he thinks it led Plato, to speak of 'growth of understanding':

The sophists evidently thought that one should speak only of the growth and multiplication of competence. Plato was talking about growth in a different sense. I suppose about understanding in a different sense also. As regards growth: we have the question of what the difference is between that and addition to a collection. I suppose it should be growth of what was there: development of that, and alteration of that. Not simply addition to it, leaving it as it was. The importance of unity again. One and not many ('Knowledge of many things does not bring understanding'). Rather of coming to see things differently, of becoming wiser, not of learning more things or skills ... [but] of understanding things or failing to understand them. And that was the kind of difference that Plato spoke of as the difference between waking and dream, of passing from illusion and twilight and darkness into light. ${ }^{112}$

Competence and proficiency leave me with the question of the 'point' of one's having or developing such competence or proficiency. And 'seeing the point' here seems to be a matter of seeing these activities in connection with the rest of 'life'. Thus, as Rhees says, 'the importance of unity again'. But, no doubt, where the understanding is not a matter of competence or proficiency, it may seem unclear what it really amounts to. And this may lead to the idea that if you really have any such understanding of 'life', then you ought to be able to say what it is, which will itself lead to trouble. 
Suppose I want to say that Rhees himself shows a remarkable understanding of 'life'. That does not mean that any particular expression of it will be intelligible to just anyone at all. Neither, however, does it mean that any particular expression of it will amount to a description of it. In an important sense, there can be no description of it. If I think Rhees shows a profound understanding of life or of philosophy, this will show in what he says, and in his writings. But any description of the understanding that does show there will have a generality to it that Rhees's own remarks and writings will belie. That is part of the point of going back to his own words, his own way of making a point, again and again. But even here, there can be no 'complete' representation of his understanding, because such understanding is itself something that shows not only in what Rhees has said, but also in what he would say. And the problem with that is not merely that death has put an end to his saying anything. The point applies to anyone living. It is tempting to say that the point is simply that understanding is itself a living thing. It shows in what a person says and does. But what a person says and does turns on what it is that he or she finds intelligible and unintelligible. And there can be no description of that distinction simply because there can be no saying in advance what a person will say, and not merely because we could only guess at which of the available options he might choose. There is no sense to such a notion of 'available options'. In reply to the objection that if you can tell the difference between intelligible discourse and nonsense, then surely you can say what the difference is, Rhees remarks:

If you raise that objection, then you have not seen what discourse is. (You have not seen the difference between language and a wallpaper pattern.) You have not seen that language should actually be spoken and understood. ${ }^{113}$

You have not seen that language should be spoken and understood insofar as you have not seen that the attempt to say "what makes language intelligible ${ }^{114}$ is itself an instance of 'thought trying to catch its own tail'. ${ }^{115}$ The distinction between sense and nonsense shows in the fact that you can say something. But to persist in asking for an account of that distinction is to fail to see that the reality of that distinction belongs to the lives that are lived by individuals and not to anything that could be described, including any 'world-view' or 'world-picture' or 'form of life' or 'way of life'. Rhees writes:

Perhaps there is some confusion between life and a way of living (or form of life). The unity of life is not the unity of a form. Any more than it is the unity of 
a skill or of an operation. It seems as though a way of life were something you could describe - 'this is what people do' - rather as you might describe a game or a complicated technique; a performance of some sort. 'All these things form part of a way of life.' 'They do that. That belongs to the way they live., 116

But no one, we might say, lives a 'way of life'. For the very conception of any way of life is an abstraction derived from the lives people actually live. But as an abstraction it must leave behind the particularity of meaning and so the particularity of understanding that make the lives of those individuals the lives that they are. ${ }^{117}$ The point might be put by saying that what makes any life a life is the fact that an individual's understanding is not the 'common' understanding presented in any account of a 'way of life'. 118 Precisely because an individual's understanding is not 'common' there is the possibility of his saying something new and so of my learning from him. But the possibility of my learning from him itself turns on the fact that my understanding is 'incomplete'. If it were 'complete' there just would not be any possibility of learning. There would be no possibility of growth, ${ }^{119}$ for I would 'have it all figured out'. But to see what it is to speak and to understand is to see the sense in which there is not even such an 'all' to have here. On the other hand, if we say that 'growth of understanding' is always possible, that may itself raise questions about the sort of understanding Rhees is talking about. Perhaps my whole world can be turned upside down, as Callicles feared would happen to his world if he took Socrates seriously. And in that case, what is to be said of the 'understanding' I now have?

I expect that the first thing Rhees might say is that nonetheless it is understanding:

The understanding that you gain as you learn language. Not something that is given in the books or in manuals. 'What is it that you have, when you have achieved it, then?' You are able to speak and understand people. That does not mean: you are master of a technique. ${ }^{120}$

You are able to speak and to understand people. That is to say, you have something to say and can understand people when they speak to you. You can understand what individuals say and so can learn something from them. But not just 'information'. For, again, it is not the case that 'I know the meaning of the sentence, so I know what you are saying, ${ }^{121}$ :

Suppose I repeat Caesar's remark. 'It is because the words have those meanings, that you have only to repeat it in order to tell me what he said.' The words 
which Jesus used on the cross were the words of Isaiah. The words which the judge uses in pronouncing sentence. An exclamation like 'Fire!' The repetition of a proverb (A rolling stone gathers no moss). ${ }^{122}$

I can come to see sense where I did not see it before, or I may see that what I thought made sense does not. But you cannot do justice to what I come to see or even to what I have left behind if you talk of all of this in terms of 'movement' or 'change' from one world-view or perspective to another. That is to leave out precisely the understanding I had and the understanding I have come to. It is to see only change or movement, but not growth: '[G]rowth of what was there: development of that, and alteration of that. Not simply addition to it, leaving it as it was. ${ }^{123}$ Nor simply replacement of it with something else. Perhaps the reality of such growth is best seen in the fact that I may come to see sense where I did not or come to see that what I thought made sense does not, not only by listening to others. I can also learn in this way from what I find myself saying. The 'reality' of discussion lies in both of these possibilities. The idea of "what I find myself saying' is connected with the fact that the distinction between sense and nonsense is nothing that can be 'told' to me nor anything I can decide upon. In this sense, I discover it, which itself suggests a sense in which the language I speak is, after all, 'responsible' to something - even if not to anything in relation to which it could be judged 'adequate' or 'inadequate'. But perhaps this is just a way of saying that the difference between sense and nonsense is not arbitrary. Regarding the notion that it might be, Rhees remarks:

Was this the sort of thing Plato was trying to emphasize? That the forms, or whatever else we are to include among the conditions of the possibility of discourse, may seem to be in some sense 'intellectual', in the sense that they do not belong to the physical objects which we see and handle. But on the other hand they are not products of our intellects or imaginary webs we weave in the air. They are not idle or empty principles - even though we cannot point to physical happenings in confirmation. ${ }^{124}$

Rhees goes on to consider an analogy between, on the one hand, sense and nonsense and, on the other hand, fact and fiction. Facts are what they are whether we like it or not. With the principles of grammar, or whatever we want to say makes the difference between sense and nonsense, we might want also to say that we are concerned with fact and not fiction. We do not just 'make them up'. And yet there is something wrong with the comparison. For nonsense, as Rhees points out, is not fiction, so that whatever we speak of as making for the distinction between sense and nonsense, 'it is a 
different kind of reality (from the reality of facts) and a different kind of correspondence'. ${ }^{125}$ And yet the distinction is 'independent' of what I might like or I might choose. That is why Rhees thinks it absurd to suggest that anybody 'decided to make this sort of distinction between what has sense and what has not'. As he says, 'That distinction is presupposed in the whole notion of making a discussion (sic) of any kind. ${ }^{126}$

When Rhees says that there is something wrong in speaking of the difference between sense and nonsense by analogy with fact and fiction, he says that there would be something wrong in suggesting that we discover this difference or that we investigate to find out what it is 'in the way in which we should investigate to find out what the facts are'. ${ }^{127}$ But, again, the sense in which we do 'discover' it is a sense that goes with Rhees's own insistence that we do not decide on such things. ${ }^{128}$ One may see an analogy here with Heraclitus's talk of listening 'not to me but to the logos' (Fragment 50), or with Plato's talk of 'listening' to 'the philosophical muse'. ${ }^{129}$ Such an emphasis on listening can be seen as an expression both of the incompleteness of my own understanding and of the fact that there is something there to be understood. Perhaps it is this matter of the incompleteness of understanding that makes talk of 'blindness' or 'ignorance' seem more natural than talk of 'being mistaken' in accounts of this kind of learning. But the recognition of the incompleteness of understanding may also suggest a conception of the philosophical life as a life of that 'love of learning' so often referred to by Plato's Socrates. ${ }^{130}$ It may also suggest a connection between the philosophical life and 'a certain humility', and a certain wonder. I mean, of course, wonder at 'the possibility of understanding', wonder that, for all its incompleteness, what I have and what others have is understanding. It is not difficult to see how the recognition of this could in turn be experienced as a passing - and a very personal one - 'from darkness to light'. ${ }^{131}$

\section{NOTES}

${ }^{1}$ D. Z. Phillips was born in 1934 . He attended what was then University College, Swansea, and went on to Oxford, earning his M.A. there in 1961. After appointments at Queen's College, Dundee, at St. Andrew's and at University College, Bangor, he returned to Swansea in 1965 as a Lecturer in Philosophy. He became Professor and 
Head of Department in 1971. In 1992 he was appointed Danforth Professor of Philosophy of Religion at what was then the Claremont Graduate School and thereafter divided his time between Claremont and Swansea where, in 1996, he became Rush Rhees Research Professor. He died in 2006.

${ }^{2}$ Ithaca, 1999. Hereafter CP.

${ }^{3}$ Cambridge, 2001. Hereafter HC.

${ }_{5}^{4}$ Philosophical Quarterly, Vol. 51, No. 202 (June 2001), p. 102.

${ }^{5}$ Phillips takes on a good deal of Rhees's language in these late writings, especially the language of Rhees's 'The Fundamental Problems of Philosophy', originally published in Philosophical Investigations (Vol. 17, No. 4, 1994) but now reprinted as the Preface to the second edition of Rhees's Wittgenstein and the Possibility of Discourse, edited by D. Z. Phillips (Oxford, 2006). All of my page references to this essay will be to the latter text. For instances of Phillips's adoption of Rhees's vocabulary, see, e.g., his talk of 'wonder' in philosophy in CP, pp. 55, 56 and 61 and Rhees's talk of wonder in Fundamental Problems, pp. xii and xiii; or Phillips's talk of the 'independence' of philosophy at PC, p. 44, and Rhees's at 'Fundamental Problems', pp. ix and x; or Phillips's talk of 'contemplation' itself at Philosophy's Cool Place, p. 2 and Rhees's at Fundamental Problems, p. xiii.

${ }^{6} \mathrm{HC}, \mathrm{pp} .318-19$.

${ }^{7}$ Ibid., p. 319.

${ }^{8} \mathrm{HC}, \mathrm{p}, 324$.

${ }^{9}$ Ibid., p. 319.

${ }^{10}$ In Dialogue with the Greeks (Vol. II): Plato and Dialectic, edited by D. Z. Phillips (Aldershot, 2004), p. 160.

${ }^{11}$ Ibid., p. 160.

${ }^{12} \mathrm{HC}$, p. 5.

${ }^{13}$ CP, p. 124.

${ }^{14}$ Ibid., p. 55. And see HC, pp. 23-4, where Phillips speaks of 'wonder at the fact that people have thought about human life in different ways ...' '. (My emphasis.)

${ }^{15} \mathrm{Pp}$. xii-xiii. As noted above, this and all other quotations from this essay are taken from it as printed in Wittgenstein and the Possibility of Discourse. Hereafter WPD.

${ }^{16}$ CP, p. 56.

${ }^{17}$ Ibid.

${ }^{18}$ WPD, p. xii.

${ }^{19}$ Ibid.

${ }^{20}$ Ibid.

${ }^{21}$ That this was indeed a 'preoccupation' is especially evident, perhaps, in WPD and in the two volumes of In Dialogue with the Greeks, as will be made clear, I hope, below. ${ }^{22} \mathrm{Pp}$. viii-ix. And see p. xi where Rhees suggests a sense in which these central questions in philosophy are 'fundamental': not fundamental to philosophy, even if they are 'central' to it; but 'fundamental' in a way that questions in, say, science are not. These remarks suggest that the title 'The Fundamental Problems of Philosophy' may not quite hit the mark. See also p. xiii and note 26 below.

${ }^{23}$ Ibid., p. xiii. 
${ }^{24}$ Volume 2, p. 39.

${ }^{25}$ See, e.g., ibid., pp. 40, 43-4 and 133.

${ }^{26}$ Ibid., pp. 39 and 44.

${ }^{27}$ WPD, p. xiii. Here, I take it, is some of what lies behind Rhees's conception of the 'central' questions of philosophy as 'fundamental' to other areas of inquiry.

${ }^{28}$ On this point see his discussions of the Pre-Socratics in Volume I of In Dialogue with the Greeks, especially Chapter One and, in particular, pp. 4-5.

${ }^{29}$ Ibid., p. viii.

${ }^{30}$ Ibid., p. xiii.

${ }^{31}$ Ibid.

32 See In Dialogue with the Greeks, Vol. II, p. 40. But see also Rhees's remarks in the appendix to WPD (p. 264) on Wittgenstein's remark, 'In philosophy he wins the race who gets there last.' And compare, perhaps, Socrates's caution regarding his own 'eagerness' in discussion at Phaedo, 91a-c.

${ }^{33}$ E.g., at Phaedo 67b, 82c and d or Phaedrus $230 \mathrm{~d}$.

${ }^{34}$ See, e.g., WPD, pp. 14, 15-16 and 18. This is a point I shall return to below.

${ }^{35}$ See p. 130 and pp. 58-9.

${ }^{36}$ See CP, p. 130 , as well as pp. $154-55$ and 158 .

${ }^{37}$ For an instance of the use of this last expression, see CP, pp. 54-5. For one example from among many of Phillips discussing such failures 'to do justice,' see CP, pp. 1634.

${ }^{38}$ See, for example, Wittgenstein's 'On Certainty': There Like Our Life (edited by D. Z. Phillips, Oxford, 2003), pp. 64-5.

${ }^{39}$ Pp. 159-60.

${ }^{40}$ Rhees is explicit about the links between philistinism, sophistic argument and scepticism at p. 248 of the second volume of the latter work, though his understanding of those links is obvious, I should think, well before that.

${ }^{41}$ P. 254.

${ }^{42}$ For examples of such references see CP, pp. 130, 153 and 160, as well as Phillips's introduction to Rhees's Moral Questions (edited by D. Z. Phillips, London, 1999), pp. xvi-xvii.

${ }^{43}$ Discussions of Wittgenstein (London, 1970), p. 102.

${ }^{4}$ Ibid., p. 100.

45 See Philosophical Investigations (hereafter PI), \#89: 'Logic lay, it seemed, at the bottom of all the sciences. - For logical investigation explores the nature of all things. It seeks to see to the bottom of things and is not meant to concern itself whether what actually happens in this or that. - It takes its rise, not from an interest in the facts of nature, nor from a need to grasp causal connexions: but from an urge to understand the basis, or essence, of everything empirical.'

${ }^{46}$ PI, \#371.

${ }^{47}$ P. 226.

${ }^{48}$ In HC, p. 292, Phillips refers to Nicholas Wolterstorff's 'Reformed Epistemology', in Philosophy of Religion for the Twenty-First Century, edited by Phillips and Timothy Tessin (Basingstoke, 2001). Kai Nielsen raised the same criticism as long ago as 1971. 
On this see Phillips in Belief, Change and Forms of Life (Atlantic Highlands, NJ, 1986), p. 12.

${ }^{49}$ P. 181.

${ }^{50}$ P. 292.

${ }^{51}$ Ibid. p. 293.

${ }^{52}$ WPD, p. 37.

${ }^{53}$ See, for example, Phillips's criticisms of Bernard Williams and Richard Rorty in CP, pp. 65-70.

${ }^{54}$ See, for example, Phillips's discussion of the relation between the common idea that 'science corresponds to reality, but magic does not' and the notion that the language in which we express our beliefs is itself a 'set of beliefs about reality' in HC, p. $292 \mathrm{ff}$.

${ }^{55}$ WPD, p. ix.

${ }^{56}$ Ibid., p. 14.

${ }^{57}$ Ibid., p. 18.

${ }^{58}$ Ibid., p. 244

${ }^{59}$ Ibid., pp. 27, 178, 188, 245. I will return to this use of 'responsible' below.

${ }^{60}$ See Rhees at p. 65 of Wittgenstein's 'On Certainty': There Like Our Life, and see Phillips in the post-script to the same text, p. 170.

${ }^{61}$ From, for example, 'Belief and Loss of Belief' (Sophia, 1970, reprinted in Wittgenstein and Religion (Basingstoke, 1993)) to the concluding chapter of HC.

${ }^{62} \mathrm{HC}, \mathrm{p} .324$.

${ }^{63}$ P. 181.

${ }^{64}$ In his 'Afterward' to Rhees's Wittgenstein's 'On Certainty': There Like Our Life (p. 176), in the course of a discussion of Wittgenstein's use of the expression 'worldpicture', Phillips wants to say that 'our world picture is not the foundation of the lives we lead, since it is the lives we lead which make our world-picture what it is.' 'Worldpicture' and 'our life' he says, 'go together': 'That is a central emphasis in Rhees's own work'. There is surely something right in this. He also goes on to speak (p. 179) of the sense in which, for Rhees, 'our language and our lives go together'. There is much that is right is this suggestion, as well. But what is right in it derives largely, I think, from Rhees's criticisms of Wittgenstein's talk of 'forms of life', something Phillips has little to say about in his 'Afterward' or, I think, elsewhere. He does mention Rhees's criticisms of Wittgenstein's use of 'form of life' in his introduction to Wittgenstein and the Possibility of Discourse, p. xxxi. But he does not pursue the point.

${ }^{65}$ See both the introduction to WPD and the 'Afterward' to Wittgenstein's 'On Certainty': There Like Our Life. But see the previous note as well.

${ }^{66}$ P. 101.

${ }^{67} \mathrm{PI}, \# 199$.

${ }^{68}$ Ibid., \#202.

${ }^{69}$ Ibid., \#242.

${ }^{70}$ See, for example, ibid., \#97.

${ }^{71}$ Ibid., \#241.

${ }^{72}$ WPD, pp. 51 and 164.

${ }^{73}$ Ibid., p. 118. 
${ }^{74}$ Ibid., pp. 45 and 186.

${ }^{75}$ Ibid., p. 27.

${ }^{76}$ Ibid., p. 45.

${ }_{78}^{77}$ Ibid., p. 46.

${ }^{78}$ Ibid., p. 119.

${ }^{79}$ Ibid., p. 87.

${ }^{80}$ Ibid., pp. 86-7.

${ }^{81}$ Ibid., p. 125.

${ }^{82}$ Ibid., p. 62.

${ }^{83}$ Ibid., p. 91.

${ }^{84}$ Ibid., p. 161 and pp. 168-9.

${ }^{85}$ Ibid., pp. 168-9.

${ }^{86}$ Ibid., p. 146.

${ }^{87}$ Ibid.

${ }^{88}$ Ibid., pp. 161-62.

${ }^{89}$ Ibid., p. 168.

${ }^{90}$ Ibid., p. 119.

${ }^{91}$ Ibid., p. 126.

${ }^{92}$ Ibid., p. 184.

${ }^{93}$ Ibid., p. 204.

${ }^{94}$ Ibid.

${ }^{95}$ Ibid., p. 182.

${ }^{96}$ Ibid., p. 183.

${ }^{97}$ Ibid., p. 88, and pp. 182-82.

${ }^{98}$ Ibid., p. 88.

${ }^{99}$ Ibid., p. 13. And see In Dialogue with the Greeks, Volume II, p. 159: 'Plato holds that where language and life are concerned, one has sense only if the other does - and only then.'

${ }^{100}$ WPD, p. 13.

${ }^{101}$ Ibid., p. 4.

${ }^{102}$ Compare what he says of Plato's conception of 'growth of understanding': 'If Plato spoke of 'understanding life', this may have thrown a certain light on what he meant; but it would not have been an answer to the question of the sophists, because for him the conception of 'life' and the conception of 'growth of understanding' were so nearly identical.' Ibid., p. 11.

${ }^{103}$ Ibid., pp. 11-12.

${ }^{104}$ Ibid., p. 69.

${ }^{105}$ Ibid., p. 115.

${ }^{106}$ Ibid., p. 148.

${ }^{107}$ Ibid.

${ }^{108}$ Ibid., p. 29.

${ }^{109}$ Ibid., p. 28.

${ }^{110}$ Ibid., p. 17. He sees problems with this idea. In particular, he thinks that it 'seems to lead to the idea of "philosophy as a science"; but he also thinks it important insofar 
as it stands in opposition to the 'practicality and philistinism which the sophists were purveying'. The latter is the main point in the present context, while the temptation to let the idea carry us to a conception of philosophy as 'science' is, in a sense, what the remainder of this essay works to avert.

${ }^{111}$ Ibid., p. 15.

${ }^{112}$ Ibid.

${ }^{113}$ Ibid., p. 11.

${ }^{114}$ Ibid., p. 94.

${ }^{115}$ Ibid., p. xx.

${ }^{116}$ Ibid., p. 118.

${ }^{117}$ I take it that this is at least part of what lies behind M. O'C. Drury's distinction between the sense in which there can be a science of psychology and the sense in which there cannot. See Chapter 2 of The Danger of Words (London, 1973).

118 Whether in this essay I am only replying to Phillips's question to me about what is to be learned from philosophical contemplation with an answer he already had - which would in turn suggest that I did not understand his question in the first place - seems to me to turn on the question whether in the last two chapters of HC, Phillips appears to see the force of the point made in this sentence. And, in all honesty, I am not sure how to answer this question.

${ }^{119}$ See WPD, p. 93, on the reality of discussion as entailing the possibility of growth. The point is very much connected with the distinction between a conversation and a performance, on which see WPD, p. 81.

${ }^{120}$ Ibid., p. 244.

${ }^{121}$ Ibid., p. 184.

${ }^{122}$ Ibid.

${ }^{123}$ Ibid., p. 15.

${ }^{124}$ Ibid., p. 247.

${ }^{125}$ Ibid.

${ }^{126}$ Ibid. The text has 'discussion'. But I wonder if it should not be 'decision'.

${ }^{127}$ Ibid.

${ }^{128}$ But neither, he wants to say, is any of this a matter of 'metaphysical faith', as if one could ask 'whether perhaps reality does not correspond to language (or: whether no reality corresponds to language)'. See ibid., p. 36.

${ }^{129}$ Philebus, 67b.

${ }^{130}$ E.g., at Phaedo $67 \mathrm{~b}$ and $82 \mathrm{c}-\mathrm{d}$ or Phaedrus 230d.

${ }^{131}$ I am grateful to Heidi Northwood for helpful discussions of an earlier draft of this essay. I have also benefited from conversations with Christopher Edelman and Matthew Edelman regarding particular points in it.

\section{WORKS CITED}

Mulhall, Stephen. Review of Philosophy's Cool Place, by D. Z. Phillips. Philosophical Quarterly. Vol. 51. No. 202 . June, 2001. 
Phillips, D. Z. Philosophy's Cool Place. Ithaca. 1990.

Religion and the Hermeneutics of Contemplation. Cambridge. 2001.

Plato. Phaedo. In Euthyphro, Apology, Crito, Phaedo, Phaedrus. Translated by H. N. Fowler. Loeb Classical Library. Cambridge, MA. 1995. (First published 1914.)

Phaedrus. In Euthyphro, Apology, Crito, Phaedo, Phaedrus. Translated by H. N. Fowler. Loeb Classical Library. Cambridge, MA. 1995. (First published 1914.)

Philebus. In The Statesman, Philebus, Ion. Translated by H. N. Fowler. Loeb Classical Library. Cambridge, MA. 1995 (First published 1925.)

Rhees, Rush. 'The Fundamental Problems of Philosophy'. Philosophical Investigations. Vol. 17. No. 4. 1994.

In Dialogue with the Greeks (Vol. I): The Pre-Socratics and Reality. Edited by D. Z. Phillips. Aldershot. 2004.

In Dialogue with the Greeks (Vol. II): Plato and Dialectic. Edited by D. Z. Phillips. Aldershot. 2004.

Moral Questions. Edited by D. Z. Phillips. London. 1999.

Wittgenstein and the Possibility of Discourse. Second Edition. Edited by D. Z. Phillips. Oxford. 2006.

Wittgenstein's 'On Certainty': There Like Our Life. Edited by D. Z. Phil$\varlimsup$ lips. Oxford. 2003.

Wittgenstein, Ludwig. Philosophical Investigations. Translated by G. E. M. Anscombe. Oxford. 1953. 
